Веселка Желязкова (София)

\title{
ПАРИМЕЙНЫЕ ЧТЕНИЯ В ЧЕТЬИХ СПИСКАХ КНИГИ ИСХОД
}

$\mathrm{B}$ средневековой славянской письменности Книга Исход, как и большинство ветхозаветных книг, сохранилась в двух функциональных разновидностях: богослужебной и небогослужебной. Богослужебная версия содержится в Паримейнике, а с XIII в. также в Триоди и в Минее. В палеославистике не подлежит сомнению факт, что Паримейник был переведен Кириллом и Мефодием одновременно с Евангелием-апракосом, служебным Апостолом и Псалтырью, поскольку он принадлежал к числу книг, без которых не могло совершаться богослужение ${ }^{1}$. Лингвистические данные подтверждают это предположение: анализ лексики и характерных особенностей перевода показывает сходство между Паримейником и древнейшими редакциями Евангелия, Апостола и Псалтыри. Паримейник известен более чем в 70 списках, которые относятся к разным редакциям и группам. Самое существенное деление - это деление на вид древний (представленный в большинстве списков) и вид более поздний, который связывается с деятельностью болгарских книжников на Афоне или в Константинополе в XIII-XIV вв. Богослужебная разновидность книги Исход исследована довольно хорошо в 80-90-ых годах прошлого века А.А. Пичхадзе 2 . Ею же подготовлено и издание паримейных чтений Книги Исход, основанное на предварительном текстологическом исследовании 32 списков Паримейниказ ${ }^{3}$ Благодаря этому изданию мы имеем хорошее представление о первоначальном паримейном переводе книги Исход, а также, благодаря подробному критическому аппарату издания, о дальнейшей истории памятника - о редакторских переработках и стихийных изменениях. В Паримейнике содержится 16 паримий из книги Исход, которые входят во все его отделы: рождественский (чтения на Рождество и Богоявление), триодный (круг чтений начиная с Сырной

${ }^{1}$ О. Новицкий, О первоначальном переводе Священого писания на славянский язык, Киев 1837, p. 18.

${ }^{2}$ А.А. ПичхадзЕ, Типология паримейньхх чтений книги Исход, Pbg 10.1, 1986, p. 20-34; еАDем, К истории ставянского Паримейника (паримейные чтения книги Исход), [in:] Традиции древнейшей славянской письменности и языковая культура восточных славян, еd. В.П. ВомПерСКий, Москва 1991, p. 147-173.

${ }^{3}$ А.А. ПичХАДЗЕ, Книга „Исход” в древнеславянском Паримейнике, УЗРПУ 4, 1998, р. 5-60. 
недели и заканчивая неделей всех святых) и месячный (чтения на праздники и нарочитые дни по месяцеслову).

Небогослужебный (четий) перевод книги Исход появился позднее. Исторические источники свидетельствуют, что полный перевод Восьмикнижия был выполнен Мефодием. В этом переводе сохранилась книга Руфь в хорватском глаголическом бревиарии 1396 г. ${ }^{4}$, но перевод остальных книг Восьмикнижия утрачен. Списки, которые дошли до нас, отражают новый перевод, сделанный в Х в. в Болгарии 5 . Возможно, в этом переводе в какойто мере использован первоначальный мефодиевский перевод 6 . На основании ряда архаических черт в некоторых списках книг Бытия и Судей был сделан вывод, что в этих списках довольно хорошо сохранились особенности этого первоначального перевода ${ }^{7}$.

Впервые некоторые наблюдения над славянской рукописной традицией четьей версии книги Исход представила А. Пичхадзе ${ }^{8}$. Ее исследования параллельно были продолжены украинской исследовательницей Т. Вилкул ${ }^{9}$ и мною ${ }^{10}$.

Установлено, что славянская рукописная традиция книги Исход сохранилась в трех разновидностях: южнославянской, русской и промежуточной (согласно А. Пичхадзе) или хронографической (согласно Т. Вилкул). В рамках этих групп выделяются и подгруппы. Так, А. Пичхадзе разделяет русскую группу на две большие группы: 1. Списки без глос и исправлений по еврейскому тексту и 2. Списки с глоссами и исправлениями по еврейскому тексту. В зависимости от характера паримейных чтений первая группа делится на две подгруппы: списки, в которых текст некоторых паримий совпадает с текстом южнославянской группы („ранняя” группа) и списки, в которых текст паримий совпадает с поздней редакцией Паримейника („поздняя” группа) ${ }^{11}$.

\footnotetext{
${ }^{4}$ А.В. Михайлов, Древнеславянский перевод кн. Рубъ, РФВ 60, 1908, p. 1-36.

${ }^{5}$ И.Е. Евсевв, Григорий пресвитер, переводчик времени иаря Симеона, ИОРЯС 3, 1902, p. 356-366.

${ }^{6}$ А.А. Алексевв, Кирилло-мефодиевское переводческое наследие и его исторические судьбы, [in:] Х международный съезд славистов. История, культура, этнография и фольклор славянских народов, еd. И.И. Костюшко, Москва 1988, p. 134-135.

${ }^{7}$ Т. СлАвова, Следи от Методиев превод на библейската книга Битие, Pbg 19.1, 1995, p. 53-70; ЕADEм, Библейското Осмокнижие в състава на Архивния хронограб, Pbg 34.3, 2010, p. 26-48.

${ }^{8}$ А.А. ПичхАДзЕ, К истории четьего текста славянского Восьмикнижия, ТОДРЛ 49, Санкт-Петербург, p. 10-21.

${ }^{9}$ Т.Л. Вилкул, Книга Исход. Древнеславянский полный (четий) текст по спискам XIV-XVI веков, Москва 2015.

${ }^{10}$ В. Желязкова, Орфографические и фонетические особенности книги Исход по рукописи № 3 из собрания Е. Барсова в Государственном историческом музее в Москве, [in:] Jеws and Slavs: Judaeo-Bulgarica, Judaeo-Russica et Palaeoslavica, vol. XV, ed. W. Mosкovich, S. Niкolova, Jerusalem-Sofia 2005, p. 138-146; ЕADEм, Средневековая болгарская рукописная традиция книги Исход, [in:] Jews and Slavs: Messianic Ideas in Jewish and Slavic Cultures, vol. XVIII, ed. W. Mosкоvich, S. Nikolova, Jerusalem-Sofia 2006, p. 23-31 et sqq.

${ }^{11}$ А.А. ПичХАДЗЕ, К истории четьего текста..., p. 20-21.
} 
Мои занятия всеми сохранившимися южнославянскими списками Исхода показали, что в рамках этой группы тоже выделяются две подгруппы: 1. Валашско-молдавские рукописи, антиграф которых - среднеболгарская рукопись XIV в. тырновского происхождения, и 2. Западно-болгарские и сербские рукописи ${ }^{12}$. Между двумя группами существует довольно много отличий, но в том, что касается паримейных чтений, они абсолютно идентичны, так что в дальнейшем я буду говорить просто о „южнославянских рукописях".

Итак, наличие двух разновидностей (богослужебной и небогослужебной) книги Исход ставит вопрос о том, в каком соотношении находятся они между собой, или другими словами, использован ли Паримейник (а если да, то в какой степени) во время полного перевода этой библейской книги или в X в. заново были переведены как четьи, так и паримейные части Книги Исход? Вопрос о соотношении паримейной и четьей версий библейских книг совсем не новый. Он был поставлен еще первыми исследователями славянской рукописной традиции библейских книг, привлекает внимание и современных исследователей. Так, в сравнительно новом обобщающем труде „История болгарской средневековой литературы” по этому вопросу сказано следующее:

Според мнението на изследователите впоследствие паримейният превод се включва в пълния небогослужебен (чети или тълковен) превод на старозаветните книги по няколко начина: 1) Без изменения, например паримиите в тълковните преписи на книгите на пророк Даниил и пророк Исайя, паримиите в южнославянските преписи на Осмокнижието, паримиите в чети версията на книги Царства; 2) с изменения (в редактиран вид), например паримиите от Битие в Архивския и Вилнюския хронограф и паримиите от Съдии в група южнославянски преписи; 3) в нов превод, например паримиите в тълковната версия на Книгата на пророк Иезекиил ${ }^{13}$.

Мнение, что южнославянские списки Восьмикнижия включают паримейный перевод без изменений, основано на исследованиях книги Бытия А. Михайлова ${ }^{14}$ и Т. Славовой. Т. Славова пишет:

Паримейните части на книга Битие в южнославянските преписи в голяма степен са съхранили първоначалния препис на Паримейника, запазен и в хърватските глаголически бревиари, и дори на места пазят по-древното четене, отколкото

\footnotetext{
${ }^{12}$ V. Zhelyazkova, The Headings in South Slavonic Copies of the Book of Exodus, [in:] The Bible in Slavic Tradition, ed. A. Kulik, C.M. MacRobert, S. Nikolova, M. Taube, C.M. Vakareliyska, Leiden-Boston 2016, p. 107-122.

${ }^{13}$ Т. СлАвовА, Библейски преводи, [in:] История на българската средновековна литература, ed. А. МилтеновА, София 2008, p. 96.

${ }^{14}$ А.В. Михайлов, Опыт изучения книги Бытия пророка Моисея в древнеславянском переводе, vol. I, Паримейный текст, Варшава 1912.
} 
паримейниците от XIII-XIV вв. Паримиите представят текст, редактиран от страна на преславските книжовници много по-слабо и непоследователно в сравнение с руските преписи ${ }^{15}$.

Однако наблюдения над рукописной традицией книги Исход показывают, что это по существу отлично обоснованное мнение нельзя распространять на все книги Восьмикнижия. Видимо, каждая из них имеет собственную традицию, которая не повторяет традиции других книг.

Вопрос об отношении четьего текста Исхода к паримейному поставлен и в новом издании книги Исход, в основе которого лежит Виленский хронограф, подготовленном Т. Вилкул ${ }^{16}$. В вводной части издания исследовательница делает следующие заключения: 1. Древнеболгарский переводчик сделал перевод всего Восьмикнижия, а лишь впоследствии составители редакций и кописты, каждый в отдельности, заменяли четий текст служебным; 2. В разных кодексах использован паримейник разных видов, при этом в редакциях четьего текста и даже в отдельных рукописях введены несовпадающие группы служебных чтений; 3. Можно предполагать, что писцы вносили паримейные выражения по памяти, заменяя переписываемый текст более привычным служебным; 4. В южнославянских списках использован Паримейник древнего вида, явных чтений, которые сигнализировали бы сверку по среднеболгарскому позднему виду, нет; 5. Нет ни одного кодекса с абсолютно чистым четьим текстом. В наибольшей степени четий текст сохранился в хронографической редакции и в южнославянских списках, в меньшей степени - в ранних русских рукописях, и в наименьшей степени - в более поздних русских рукописях ${ }^{17}$.

${ }_{15}$ Т. СлАвовА, Библейското Осмокнижие в..., р. 30.

${ }^{16}$ Т.Л. Вилкул, Книга Исход..., р. 18-23.

${ }^{17}$ Неоспоримым доказательством того, что практика заменять неслужебные чтения служебными существовала, является древнейший славянский список Пятикнижия, так наз. Лаврское пятикнижие. Рукопись датируется второй половиной XIV в., хранится в РГБ в Москве, в собрании Троицко-Сергиевой лавры под № 1. Еще А.В. Михайлов писал о том, что паримейные чтения в этом списке переписаны не с полного (четьего) списка, а с Паримейника, содержащего очень архаический перевод. Ученый объяснил этот факт желанием составителей сохранить паримии в той редакции, которая исконно употребляется в богослужении. Cf. A.В. Михайлов, Опыт изучения книги Бытия..., p. LVIII-LIX. Подробные текстологические и лингвистические доказательства архаичности паримейных чтений в Лаврском пятикнижии были приведены и в: Т. СлАвовА, Най-ранният славянски рбкопис на Мойсеевото петокнижие, СЛ 31, 1999, р. 54-65. Особенно интересно, что в рукописи встречается несколько контаминаций, когда четьи чтения продублированы паримейными. Напр., в Еx 1,7

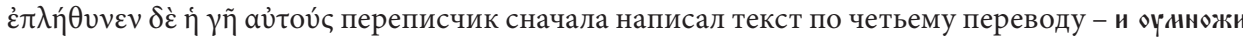
жє $\mathfrak{c A}$ зєнля, а потом продолжил по паримейному - и исполниша зєнлю тү. Аналогично в Ех 2,5

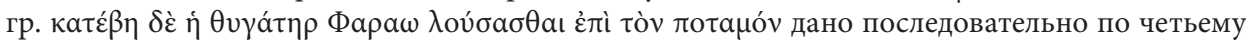

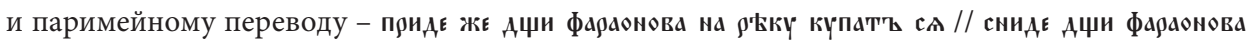

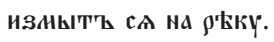


Мои собственные наблюдения полностью подтверждают эти суждения. Цель настоящей работы - подтвердить и расширить эти выводы при помощи текстологических и языковых данных. Текст книги Исход цитируется по следующим рукописям: № 3 из собрания Е. Барсова (ГИМ, Москва) 70-80-х годов XV в. (южнославянская группа, в дальнейшем Б $)$; № 44 из собрания Троицко-Сергиевой лавры (РГБ, ф. 304.I) XV в. (ранняя русская группа, в дальнейшем Тр); № 1 из собрания Е. Барсова (ГИМ, Москва) XV в.

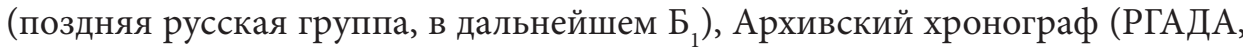
ф. 181) XV в. (хронографическая редакция, в дальнейшем Ар). Привлекается и древнейший список Пятикнижия - Лаврское пятикнижие XIV в. (РГБ, Москва, ф. 304.I). Использовано издание Григоровичева паримейника XII в. ${ }^{18}$ (Гр), а также существующее издание паримейных чтений книги Исход ${ }^{19}$. Греческий текст Исхода дается по критическому изданию Дж. Виверса ${ }^{20}$.

Полное сопоставление паримейных чтений в паримейниках и в четьих списках книги Исход показало, что отношения межу ними довольно сложные и очень трудно установить какие-то закономерности и сделать выводы, относящиеся ко всем паримейным чтениям. На самом деле выводы могут быть разными в зависимости от конкретного текста. Так, если мы рассмотрим Паримию на Страстной понедельник (Ex 1,1-20), то увидим, что текст в южнославянских списках ${ }^{21}$ примерно на 90\% совпадает с текстом Паримейника древнего типа. В рукописях поздней русской группы текст паримии следует тексту поздней редакции Паримейника (в дальнейшем ПР). В Архивском хронографе и в рукописях ранней русской группы, по-видимому, сохранен четий перевод. Например:

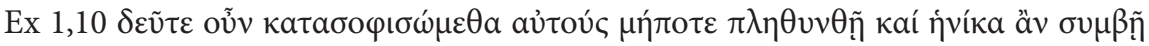

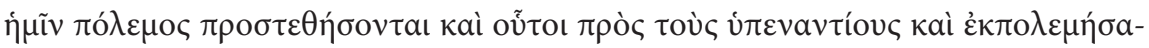

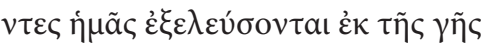

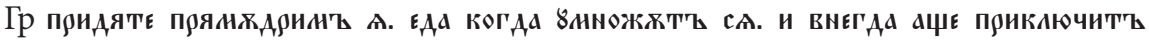

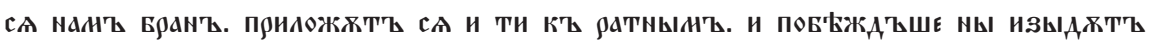
ש̈ ЗнA NAWEA.

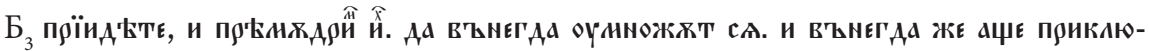

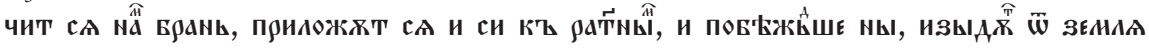
กมШA.

18 3. РИБАРова, 3. ХАУПтова, Григоровичев паримејник. Текст со критички апарат, Скопје 1998.

${ }^{19}$ А.А. ПичхадзЕ, Книга „Исход”...

${ }^{20}$ Septuaginta. Vetus Testamentum Graecum. Auctoritate Academiae Scientiarum Gottingensis editum, vol. II.1. Exodus, ed. J.W. Wevers, Göttingen 1991.

${ }^{21}$ Здесь и далее примеры из южнославянских рукописей даются по Б. 


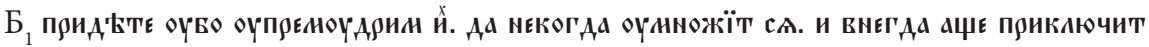

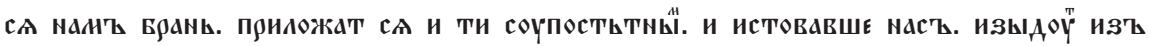
ЗЕНЫАА наШЕА.

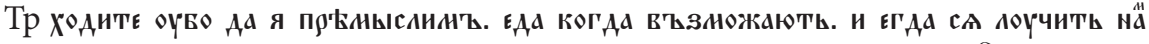

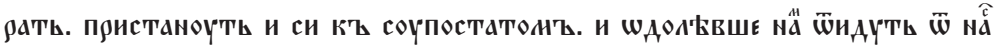

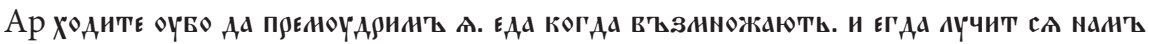

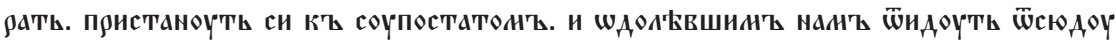

Совершенно иные отношения между паримейными чтениями в Паримейнике и четьих списках Исхода можно найти в Паримии на Страстную средy (Ex 2,11-22). С одной стороны стоит текст в древнейших паримейниках. Рукописи поздней русской группы, видимо, содержат чтения, характерные для ПР. Обеим группам довольно четко противопоставляются чтения в южнославянских списках, рукописях ранней русской группы и Архивском хронографе, в которых, без сомнения, сохранился четий перевод. Например:

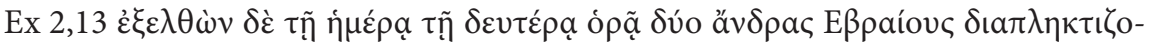

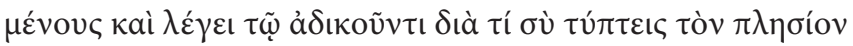

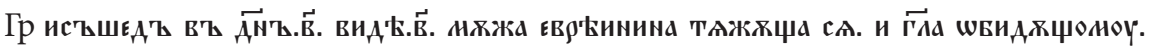
ПОчтТ БИєШИ ИСКОЪНЕГО.

Б ЧТО ९аДИ ТЫ БИЕШИ ИСКОЕНАГО.

Б ШБИААЧОНОY, ПОЧТО ТЫ БИЕШИ А९ОКГА СВОЕГО.

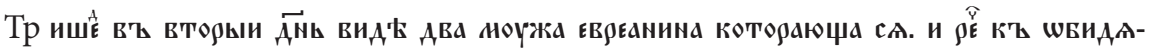

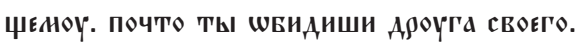

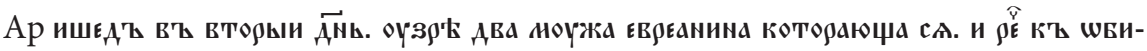

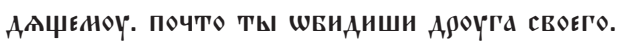

Третий тип отношений между списками мы находим в Паримии на Богоявление и Великую субботу (Ех 14,15-29). В данном случае паримейный перевод содержится как в Паримейнике, так и в рукописях ранней и поздней русской группы, однако в них текст правлен по ПР. Южнославянские списки и Архивский хронограф содержат четий перевод этой паримии. Например:

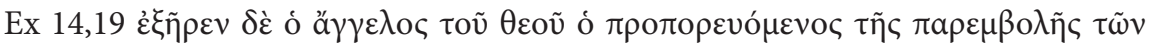
víw

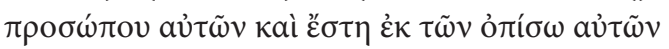




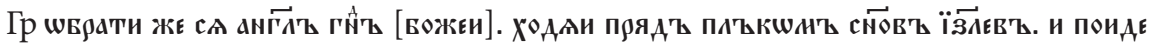

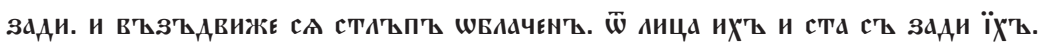

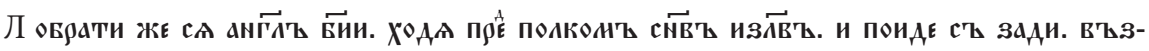

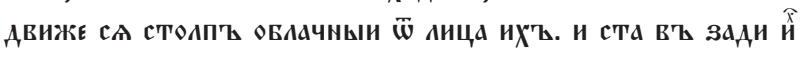

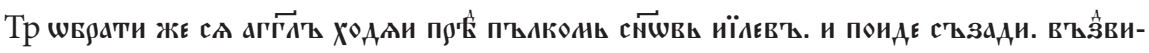

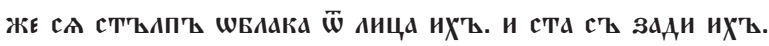

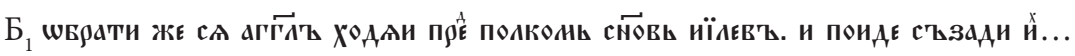

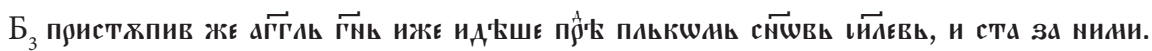

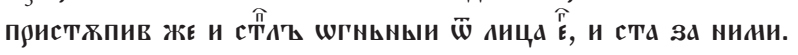

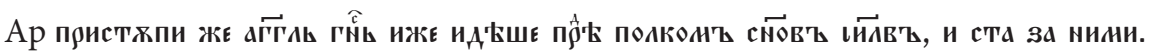

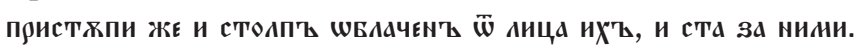

В дальнейшем изложении я хотела бы привести текстологические и лингвистические доказательства того, что паримейные чтения в небогослужебных (четьих) списках книги Исход представляют собой новый перевод. Местами он довольно сильно отличается от богослужебного перевода, находящегося в Паримейнике. Местами разница не такая серьезная, т.е. паримейный и четий перевод очень близки друг к другу. Это можно объяснить фактом, что славянский Паримейник опирается прежде всего на Лукиановую редакцию библейских книг, которая была использована и в четьем переводе. Вполне логично также, что переводчик четьего текста книги Исход был хорошо знаком с текстом Паримейника и, переводя заново библейский текст, по памяти иногда востанавливал более древний перевод.

Еще раз подчеркиваю, что четий перевод в его чистом виде не сохранился ни в одном списке. Во всех группах и кодексах есть паримейные вставки - в некоторых больше, в других меньше. Тем не менее в большинстве случаев определение четьей версии сравнительно легко. Лучше всего она представлена в Ар, далее следуют южнославянские списки. В ранних русских списках в некоторых паримиях сохранился четий перевод, а в других - четья версия заменена чтениями из ПР. В рукописях поздней русской группы четья версия не сохранилась, она почти полностью заменена чтениями из ПР.

Сначала приведу некоторые примеры, указывающие на то, что в паримейном и четьем варианте использованы разные греческие источники. На самом деле таких примеров не так много, что можно объяснить тем, что как славянский Паримейник, так и полная версия книги Исход опираются на Лукиановую редакцию. 


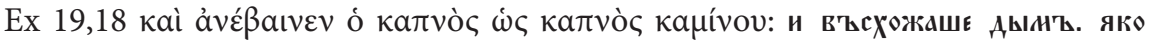

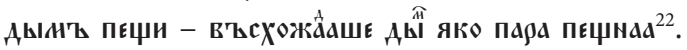

В данном случае разночетние дықы' - пара можно объяснить разночтени-

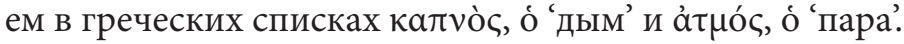

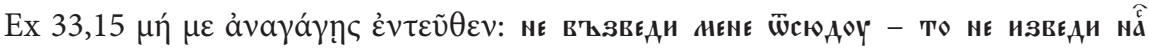
$\overline{\mathrm{w}} \mathrm{c} \boldsymbol{x}_{\mathrm{A}} 8$.

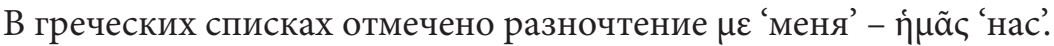

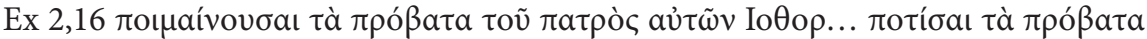

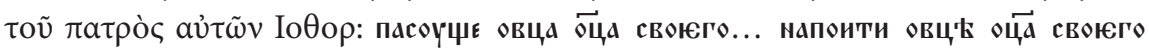

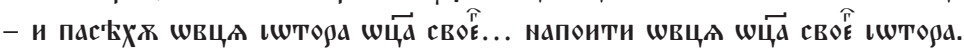

Имя еврейского священника ІоӨо присутствует не во всех греческих списках.

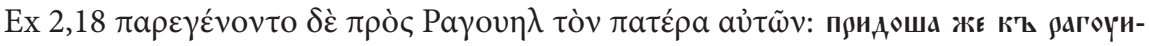

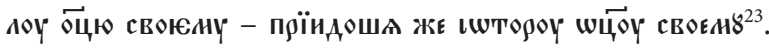

Разницу между паримейным и четьим переводом можно объяснить разночтением Раүоuп $\lambda$ - IоӨо в греческих списках.

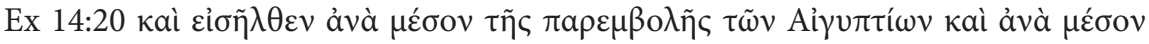

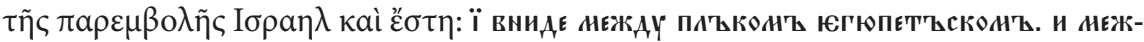

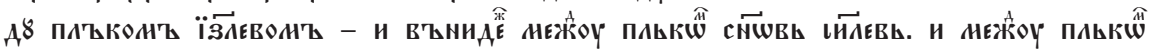
єгїпё

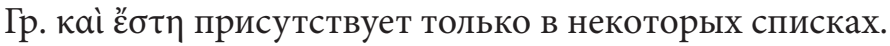

Большая часть разночтений между паримейным и четьим переводом является результатом использования различных переводческих решений.

Сначала рассмотрим грамматические варианты.

1. В паримейной версии книги Исход греческие причастия с артиклем переводятся причастием. В то же время в непаримейной версии эти причастия передаются ижє-конструкциями. Согласно мнению исследователей, первый

\footnotetext{
22 Здесь и далее с левой стороны приводятся чтения, характерные для паримейного перевода, а с правой - чтения четьего перевода.

${ }^{23}$ Разночтение встречается и в Ех 3,1 .
} 
прием характерен для кирилло-мефодиевских переводов, а второй - для более поздних переводов, осуществленных в Преславе.

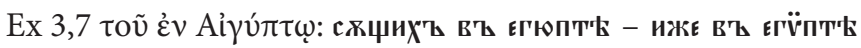

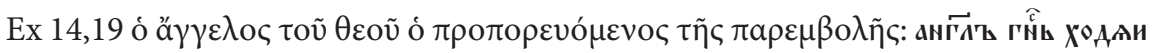

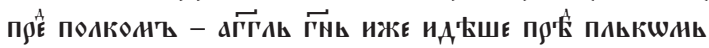

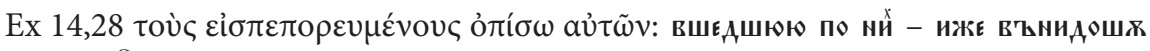
въ $\mathfrak{c}$ 咜

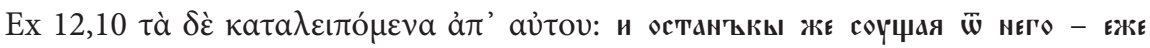
WCTANE

2. В паримейной версии книги Исход греческие причастия, как правило, переводятся причастием, а в непаримейной используются личные формы глагола.

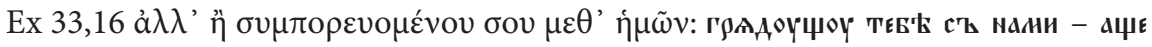
ИдеШИ ТЫ Съ нани

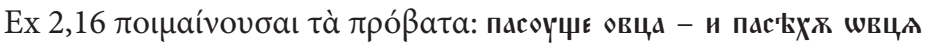

3. На месте греческого перфекта и плюсквамперфекта в паримейной версии книги Исход находим аорист или имперфект, в то время как в четьем переводе используются сложные формы глагола.

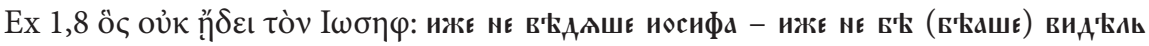
ıшсифа

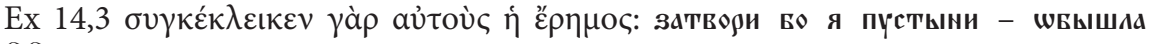
й

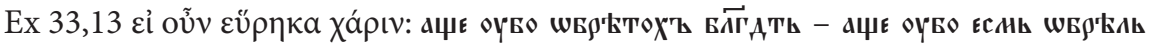
БА

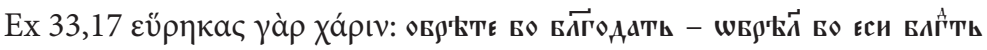

4. Для перевода греческой конструкции є̇v + дательный падеж в паримейном переводе используется беспредложный творительный, что не характерно для четьего перевода книги Исход.

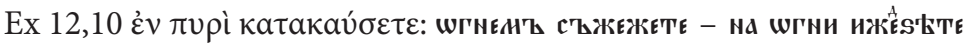

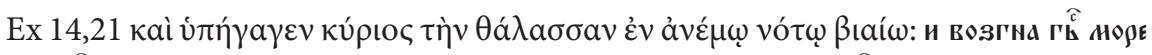

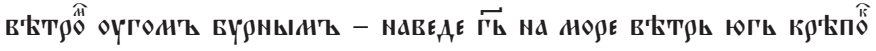




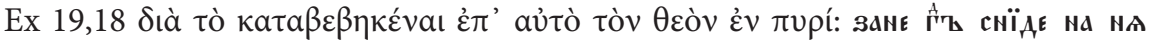

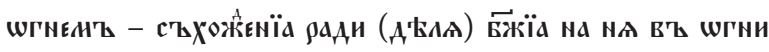

5. В некоторых случаях в паримейной версии книги Исход употреблено настоящее время глагола, а в непаримейной - аорист.

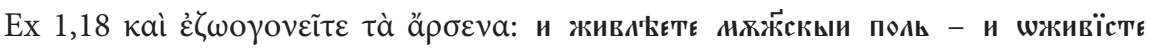
ноужскыи пол'ъ

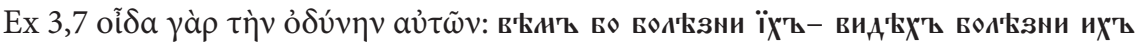

6. Довольно часто на месте страдательных конструкций, характерных для паримейной версии, в непаримейной употребляются личные формы глагола. Обратные случаи встречаются значительно реже.

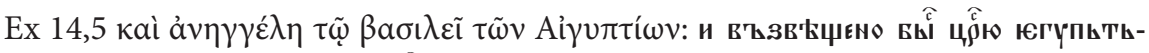

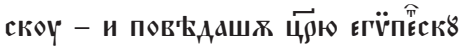

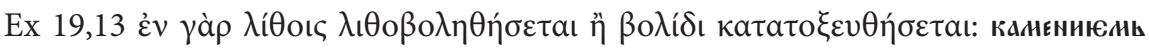

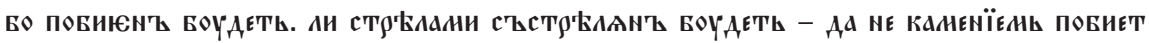

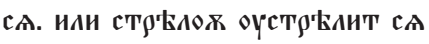

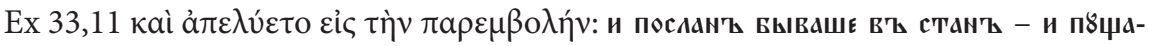
ашє и в' пล็́

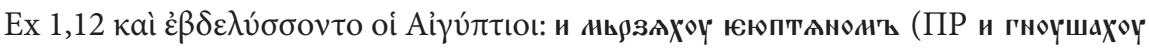

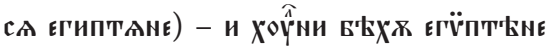

7. О разных переводческих решениях говорят и другие отличия между паримейным и четьим переводом.

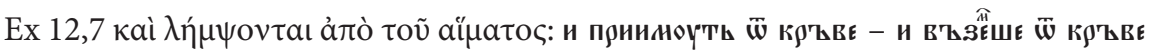

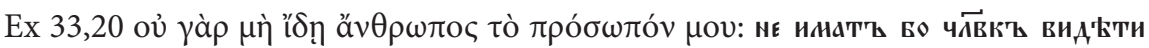

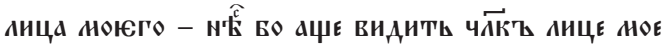

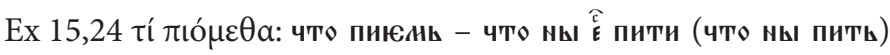

8. Для паримейной версии книги Исход характерен суффикс -ьск'ы, а для непаримейной - суффикс *-јь. Хотя пример только один, он показателен, потому что подобное соотношение характерно и для переводов книги пророка Иезекииля ${ }^{24}$.

${ }^{24}$ Старобългарският превод на Стария завет, еd. С. НиколовА, vol. II, Книга на пророк Иезекиил с тълкования, София 2003, р. 35. 


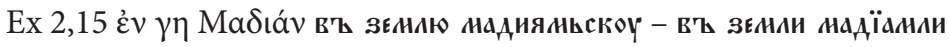

Обратим внимание на две конструкции. Считается, что беспредложные конструкции места, как и конструкции типа къжд॰ ихъ являются более архаичными и часто их присутствие в каком-нибудь тексте используется как аргумент его отнесения к кирилло-мефодиевским переводам ${ }^{25}$. Интересно, что в книге Исход архаичные конструкции характерны для полного, а не для более старого паримейного перевода. Это означает, что не во всех случаях более древнее чтение можно определить по „архаичности” языка.

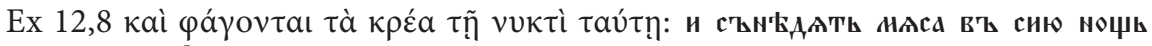

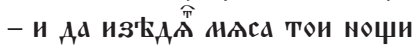

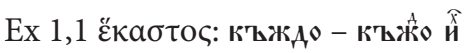

Особенно интересны лексические разночтения. В целом это лексемы, являющиеся одинаково возможными соответствиями одного греческого слова. Анализ этих разночтений показывает, что в паримейном переводе книги Исход последовательно употребляется кирилло-мефодиевская лексика, в то время как в четьем переводе находим лексемы, характерные для преславской редакции библейских книг.

На первом месте следует указать на факт, что в паримейном варианте употребляются непереведенные греческие лексемы, в то время как в четьем варианте грецизмы полностью устранены. В палеославистике общепризнано, что устранение грецизмов связано с преславской редакцией богослужебных книг ${ }^{26}$. Интересно, что для ПР грецизмы тоже не характерны.

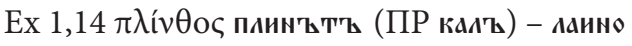

Ex 1,16 'Еßраі́а єврєаныня - жидаовыни

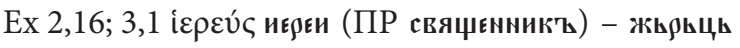

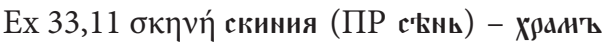

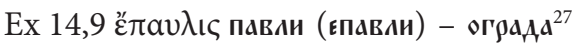

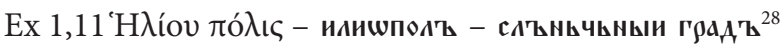

${ }^{25}$ Сf., напр., Т. СлавовА, Следи от Методиев превод..., р. 57.

${ }^{26}$ И. Доврев, Грбиките думи в Супрасълския сборник и втората редакиия на старобългарските богослужебни книги, БЕ 28.2, 1978, р. 89-98.

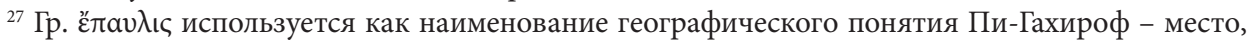
где израильтяне расположились станом перед переходом через Чермное море. Перевод буквальный и означает „неогороженное поселение”. Cf. J.W. WeVERs, Notes on the Greek Text of Exodus, Atlanta 1990, p. 218-219.

${ }^{28}$ Название египетского города Он в земле Гесем. 
В других случаях находим типичные пары, которые в палеославистике давно используются для атрибуции переводов как кирилло-мефодиевские или преславские ${ }^{29}$.

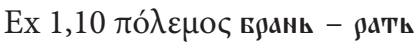

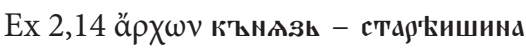

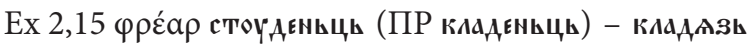

Ex 2,19 поции́v пастырь - пастоүхты

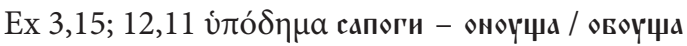

Ex 12,4 $\pi \lambda$ пбі́о искрьнии - Ближнии

Ex 13,2,15 ни́тра Аожесно - втрова

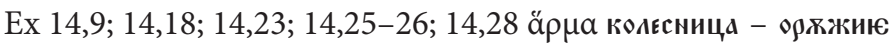

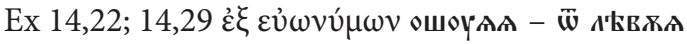

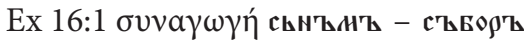

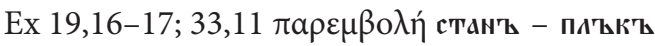

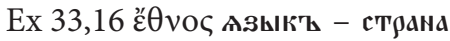

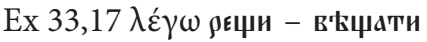

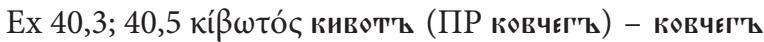

В ряде случаев вторым членом пары является лексема, характерная для восточно-болгарских письменных памятников.

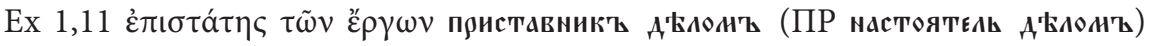

- ПоГОничь А'ЕАЕснын ${ }^{30}$

Ex 2,13

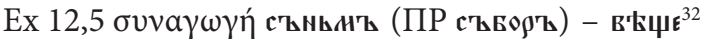

${ }_{29}^{29}$ Т. СлАвовА, Преславска редакиия на Кирило-Методиевия старобългарски евангелски превод, KMс 6, 1989, p. 15-129.

${ }^{30} \mathrm{O}$ лексеме пюгоничь и словах с суффиксом -ичь сf. В. ЖелязковА, Към историята на един словообразувателен модел, [in:] Актуални проблеми на балканистиката и славистиката. Доклади от Втората междннародна конференция, проведена на 9 и 10 ноември 2012 г. във Великотърновския университет „Св. св. Кирил и Методий”, еd. И. ХАРАЛАМПИЕв, М. СПаСовА, Ж. КолевА-ЗЛАтевА, А. ПетровА, К. Димитров, Г. ПЕНАКОвА, Велико Търново 2014, p. 80-87.

${ }^{31}$ Глагол которати с⿱㇒ 'спорить', как и существительное котоличь 'человек, который склонен к ссорам', известны из Супрасльского сборника XI в. (Старобългарски речник, еd. Д. ИвановА-МирчевА, vol. I, София 1999, p. 747). Cf. и употребление лексемы которичь в Изборнике 1073 г. (Ц. РАлевА, Имена за тица в Изборника от 1073 г. в сбпоставка с лексиката на старобългарските паметници (кандидатска дисертация, машинопис), София 1989, р. 176).

32 Лексема въцє употребляется в Супрасльском сборнике XI в. в словосочетании втцв творити на көго 'устраивать заговор против кого-н., гр. бтабıа́ 
Ex 33,12 о̉ли́ ок'ъньцє - сквожьня ${ }^{33}$

Можно указать и на целый ряд других лексических разночтений, которые тоже дают все основания утверждать, что паримии в рамках четьего текста являются новым, самостоятельным переводом.

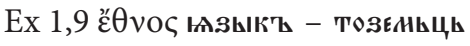

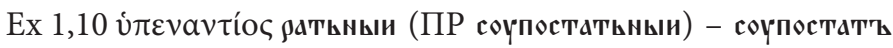

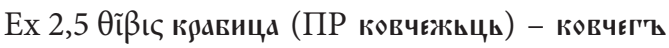

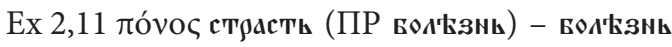

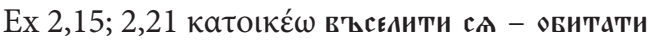

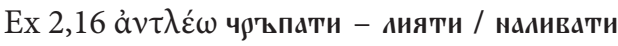

Ex 2,22 та́рокко́ п пишєАьць - оБитальникъ

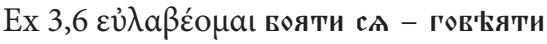

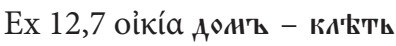

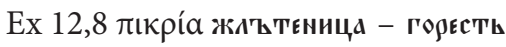

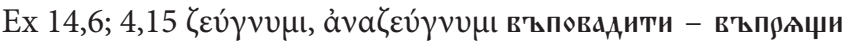

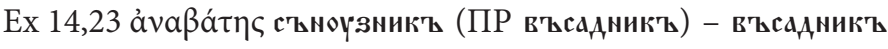

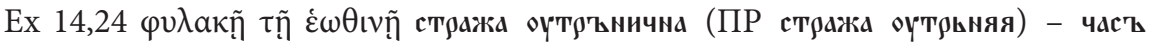
оүтерьнии

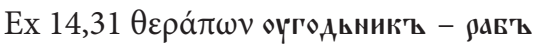

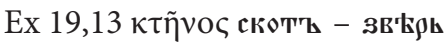

Особое внимание заслуживают те разночтения, в которых наблюдается не просто замена одного слова другим. Речь идет о целых словосочетаниях, порою целых стихах, в которых использована и различная лексика, и различные грамматические и синтаксические приемы передачи смысла. Почти во всех случаях возможно предполагать не просто различные переводческие решения, а и использование различных греческих источников. При этом почти во всех случаях ближе к греческому тексту, представленному

p. 330), восходит к праслав. *věịto и встречается во всех славянских языках (М. ФАсмеР, Этимологический словарь русского языка, vol. I, Москва 1986, p. 308). В значение 'народное собрание' довольно часто употребляется в русских летописях, в других письменных памятниках встречается сравнительно редко (И.И. СРезневскиЙ, Словарь древнерусского языка, vol. I, Москва 1989, p. 499-500). Видимо, оно являлось малоупотребимым и в XV-XVI вв. уже было непонятно книжникам, так как во всех южнославнских списках книги Исход встречается в искаженном виде - в'кка. В Ар употреблено в русской огласовке - вєчєви.

33 Лексема зафиксирована в Супрасльском сборнике, творчестве Иоанна Экзарха, Книге пророка Иезекииля с толкованиями и др. 
в критическом издании книги Исход, оказывается более старый перевод, содержащийся в Паримейнике. Варианты в четьем переводе во многих случаях стоят далеко от греческого текста, их нельзя объяснить и приведенными в критическом аппарате разночтениями. В подобных случаях возможны два предположения - или что переводчик неслужебного текста переводил более свободно и не всегда следовал точно за греческим текстом, или что при переводе четьего текста использован такой вариант греческого текста, который до нас не дошел и не нашел отражения в критическом аппарате издания.

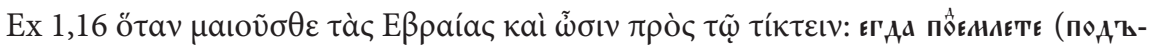

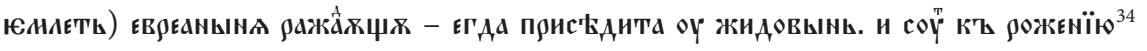

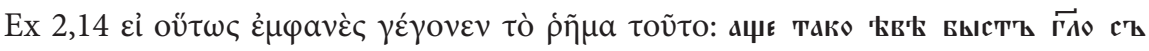

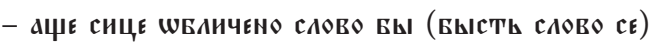

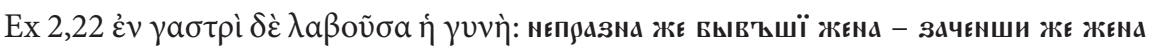
въ Аттовт

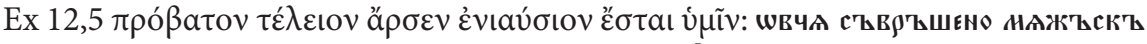

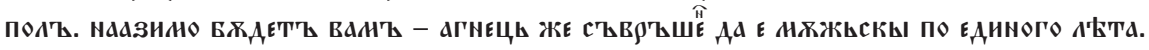

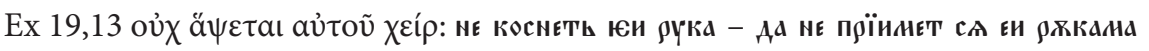

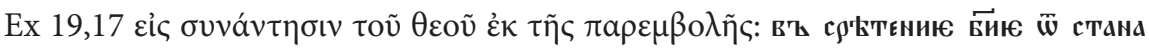

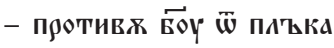

Итак, рассмотренные текстологические данные и переводческие особенности в области грамматики и лексики позволяют сделать вывод, что при переводе небогослужебного (четьего) текста книги Исход переводчик перевел всю книгу в целом, а не включил в свой перевод уже переведенные паримейные чтения. Вероятно, в некоторых паримиях и отдельных стихах он использовал служебный перевод (скорее всего, по памяти). Есть все основания связать этот новый перевод с переводами, созданными или отредактированными в Преславе. В этом отношении история богослужебных чтений Исхода не совпадает с историей других библейских книг, как, например, книги пророка Исайи и книги пророка Даниила, но зато совпадает с историей этих чтений в других богослужебных книгах, например, в книге Двенадцати малых пророков и в книге пророка Иезекииля. Особенно важно несовпадение истории богослужебных чтений книги Исход и книги Бытия. Это означает, что выводы, сделанные по отношению к одной библейской книге в составе Восьмикнижия, нельзя относить ко всему Восьмикнижию в целом. Богослужебный (паримейный) текст был внесен в четьи списки позднее и таким образом частично заменил четий перевод. Наиболее последовательно эта замена осуществлена в четьих списках поздней русской группы.

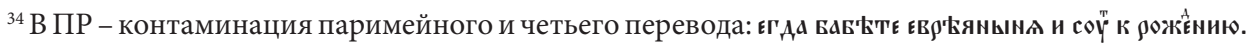




\section{Библиография}

\section{Литература}

Septuaginta. Vetus Testamentum Graecum. Auctoritate Academiae Scientiarum Gottingensis editum, vol. II.1. Exodus, ed. J.W. Wevers, Göttingen 1991.

Wevers J.W., Notes on the Greek Text of Exodus, Atlanta 1990.

Zhelyazkova V., The Headings in South Slavonic Copies of the Book of Exodus, [in:] The Bible in Slavic Tradition, ed. A. Kulik, C.M. MacRobert, S. Nikolova, M. Taube, C.M. Vakareliyska, Leiden-Boston 2016, p. 107-122.

Алексевв А.А., Кирилло-мефодиевское переводческое наследие и его исторические судьбы, [in:] Х международньй съезд славистов. История, культура, этнография и фольклор славянских народов, еd. И.И. Костюшко, Москва 1988, р. 134-135.

Вилкул Т.Л., Книга Исход. Древнеславянский полный (четий) текст по спискам XIV-XVI веков, Москва 2015.

Доврев И., Грбиките думи в Супрасълския сборник и втората редакиия на старобблгарските богослужебни книги, БЕ 28.2, 1978, p. 89-98.

Евсеев И.Е., Григорий пресвитер, переводиик времени изаря Симеона, ИОРЯС 3, 1902, р. 356-366.

Желязкова В., Орфографические и фонетические особенности книги Исход по рукописи № 3 из собрания Е. Барсова в Государственном историческом музее в Москве, [in:] Jews and Slavs: Judaeo-Bulgarica, Judaeo-Russica et Palaeoslavica, ed. W. Mosкovich, S. Niкolova, vol. XV, Jerusalem-Sofia 2005, p. 138-146.

Желязкова В., Средневековая болгарская рукописная традииия книги Исход, [in:] Jews and Slavs: Messianic Ideas in Jewish and Slavic Cultures, ed. W. Moskovich, S. Nikolova, vol. XVIII, Jerusalem-Sofia, 2006, p. 23-31.

ЖЕлязкова В, Кбм историята на един словообразувателен модел, [in:] Актуални проблеми на балканистиката и славистиката. Доклади от Втората международна конференция, проведена на 9 и 10 ноември 2012 г. във Великотьрновския университет „Св. св. Кирил и Методий, ed. И. ХАРАЛАМПИЕв, М. СПАСОВА, Ж. КОЛЕВА-ЗЛАТЕВА, А. ПЕТРОвА, К. ДИМИТРОВ, Г. ПЕНАКОВА, Велико Търново 2014, р. 80-87.

Михайлов А.В., Древнеславянский перевод кн. Руфь, РФВ 60, 1908, p. 1-36.

Михайлов А.В., Опыт изучения книги Бытия пророка Моисея в древнеставянском переводе, vol. I. Паримейный текст, Варшава 1912.

Новицкий О., О первоначальном переводе Священого писания на славянский язык, Киев 1837.

Пичхадзе А.А., Типология паримейных чтений книги Исход, Pbg 10.1, 1986, p. 20-34.

ПичхадзЕ А.А., К истории славянского Паримейника (паримейные чтения книги Исход), [in:] Традищии древнейщей славянской письменности и языковая культура восточных славян, ed. В.П. Вомперский, Москва 1991, p. 147-173.

ПичХАДзЕ А.А., К истории четьего текста славянского Восьмикнижия, ТОДРЛ 49, Санкт-Петербург 1996, p. 10-21.

Пичхадзе А.А., Книга „Исход” в древнеславянском Паримейнике, УЗРПУ 4, 1998, p. 5-60. 
РАлева Ц, Имена за лииа в Изборника от 1073 г. в съпоставка с лексиката на старобългарските паметници (кандидатска дисертация, машинопис), София 1989.

Риварова 3., З. ХАУПтова, Григоровичев паримејник. Текст со критички апарат, Скопје 1998.

Славова Т., Преставска редакция на Кирило-Методиевия старобългарски евангелски превод, KMc 6, 1989, p. 15-129.

Славова Т., Следи от Методиев превод на библейската книга Битие, Pbg 19.1, 1995, p. 53-70.

Славова Т., Най-ранният славянски ръкопис на Мойсеевото петокнижие, СЛ 31, 1999, p. 54-65.

Славова Т., Библейски преводи, [in:] История на българската средновековна титература, София 2008, p. 93-103.

Славова Т., Библейското Осмокнижие в състава на Архивния хронограф, Pbg 34.3, 2010, p. 26-48.

СрезневСКий И.И., Словарь древнерусского языка, vol. I, Москва 1989.

Старобългарският превод на Стария завет, ed. С. НиколовА, vol. II, Книга на пророк Иезекиил с тәлкования, София 2003.

Старобългарски речник, еd. Д. Иванова-Мирчева, vol. I, София 1999.

ФАСмер М., Этимологический словарь русского языка, vol. I, Москва 1986.

\begin{abstract}
Paroemia readings in non-liturgical (četi) copies of the Book of Exodus. The article studies the correlation between the Slavonic liturgical and non-liturgical versions of the Book of Exodus. The linguistic-textological data as well as some variant readings allow us to conclude that during the translation of the non-liturgical (full, četi) text of the Book of Exodus the translator did not use already translated paroemias. There is every reason to associate this new translation with the texts translated or revised in Preslav in the $10^{\text {th }}$ century. The liturgical (paroemias) readings were included in the full copies of Exodus later and thus partially replaced the non-liturgical text. Most often this replacement was performed in the full copies of late Russian group.
\end{abstract}

Ключевые слова: Паримейник, Книга Исход, преславские переводы

Keywords: Book of Paroemias, Book of Exodus, Preslav translations

Veselka Zhelyazkova

Cyrillo-Methodian Research Centre

13 Moskovska str.

1000 Sofia, Bulgaria

vzhel@abv.bg 